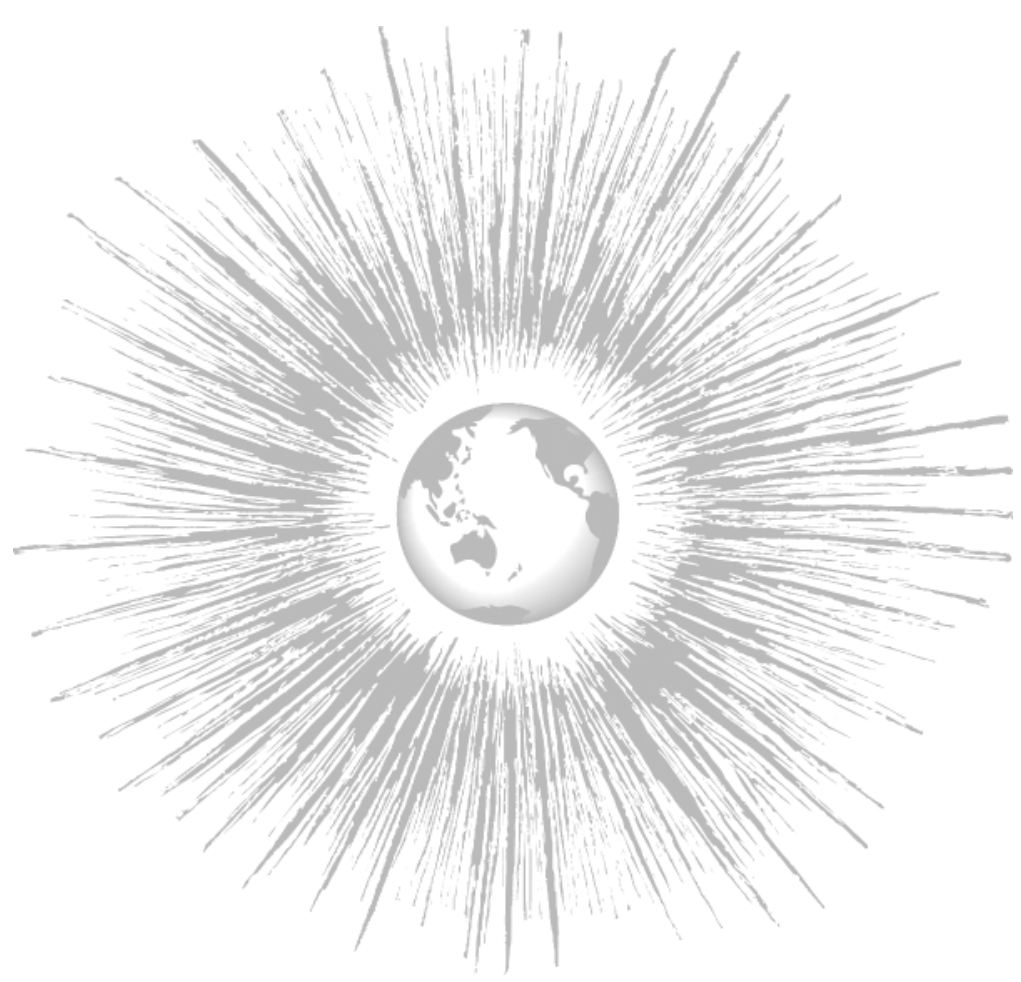

ABSTRACT:

The events of $9 / \mathrm{II}$ have rekindled interest in the social sciences concerning the global factors responsible for transnational terror ism. Two opposing frameworks currently dominate the scene: proponents of a "destruc tive globalization" approach argue that pro cesses related to the trans-nationalization of capital produce native resistance in the more economically disadvantaged areas of the globe that is manifested as transnational terrorist attacks, especially against the U.s., "civilizing globalization" arguments point to precisely the opposite effect: economic globalization through the spread of markets and materia goods brings with it prosperity and higher living standards, thus defusing the motivation to engage in high-risk political violence. In this paper, I propose an additional frame work that goes beyond the narrow realism of the destructive globalization and civilizing globalization perspectives by examining the role of the globalization of world culture in the of anti-u.s. terrorist activity.

\section{The Effect of Economic and Cultural Globalization on Anti-U.S. Transnational Terrorism I97I-2000*}

Omar Lizardo

\section{INTRODUCTION}

rganized terrorist activity produced by transnational sub-state actors and directed at American targets has been a constant feature of the post-war global arena, especially since 1968. This period has in fact been referred to as "the age of terrorism" (Laqueur 1987), making terrorism in general and anti-U.S. terrorism in particular, an important if often overlooked feature of the modern world-system (Bergesen and Lizardo 2004, 2005). This has become more important given that the salience of transnational terrorism in the global arena has intensified after the end of the cold war, a process that has reached its zenith after the events of 9/II. Virilio (2004:192) for instance, speaking of the first attempted bombing of the World Trade Center in 1993, was already referring to a "new era" of terrorism, which has"nothing in common with the explosions that regularly rock Ireland or England." Hoffman (1995), Laqueur (1999) and Ranstorp (1996) point to the new "religious" terrorism as representing a qualitative break with previous modes of political violence. Rapoport (200I) refers to this latest development as the "fourth wave" of terrorism which follows earlier anarchist, national-libera-

production of anti-U.s. terrorism. I argue that looking at the role of world cultural structuration is important because even though economic globalization may help create local grievances outside of the most economically advantaged areas of the world, cultural globalization provides the requisite models of individual and organizational action and the interpretive schemas that "empower" local actors with the constitutive capacity to engage in high-risk acts of political violence and allows them to make local/global connections. I test this framework using time-series worldlevel data in order to examine the global correlates of anti-u.s. terrorist activity for the last 30 years. The results provide mixed support for both civilizing globalization and destructive globalization viewpoints. Further, and in accord with the model proposed here, cultural globalization has a positive effect on the rate

\section{Omar Lizardo \\ University of Arizona \\ Department of Sociology \\ Social Sciences 400 \\ Tucson, AZ 85721 \\ olizardo@email.arizona.edu}

* An earlier version of this paper was presented at the Stanford University Department of Sociology Terrorism Research Group, Stanford, California, April, 2004. I would like to thank Al Bergesen for the many conversations which helped germinate the basic framework of this paper. Michelle Bata, Donald Emerson, Roger Friedland, John Meyer, and the JWSR reviewers and editors also provided helpful comments and suggestions on previous drafts.

JOURNAL OF WORLD-SYSTEMS RESEARCH, XII, I, JULY 2006, I49-I86 bttp://jwsr.ucr.edu/

ISSN $1076-156 \mathrm{x}$

(C) 2006 Omar Lizardo 
tion and Marxist waves. This "new" terrorism is seen as having acquired a more distinct transnational cast, while simultaneously losing the ideological specificity of earlier waves (in particular those inspired by Marxist ideology) and moving toward more diffuse claims and motivations (Juergensmeyer 2000; Stern 1999).

In spite of this general interest in the changing historical and cultural dynamics of terrorism as a form of political violence, most research on terrorism has ignored its more global causes and components and has instead focused on more proximate factors and mechanisms (Bergesen and Lizardo 2004). The principal focus of most terrorism research from the 1960s through the r 990 concentrated in analyzing terrorism from psychological ("the terrorist personality") and social-psychological (dynamics of recruitment, indoctrination and coordination in small organizations) perspectives (Crenshaw 1981: 389-396; Crenshaw 1992; Hoffman 1998, 1999). ${ }^{1}$ Related approaches from Economics and Political Science followed a similar tack by incorporating individualistic models of rational action and motivation which tended to ignore local contexts and structures and viewed terrorist activity as primarily driven by a putatively universal cost-benefit calculus (i.e. Sandler and Enders 2004, but see Crenshaw 198I and Ross 1993 for a multidimensional model). Needless to say, the analysts that draw on these approaches pay little attention to global structures as important causative factors of the bundle of phenomena usually classified under the heading of transnational terrorism.

More recently, primarily due to the impact of the events of $9 / \mathrm{II}$, there has been a concerted effort to try to provide explanations of terrorist phenomena from a more global perspective (Baudrillard 200I; Barber 1992; Bergesen and Lizardo 2002, 2004, 2005; Bergesen and Han 2005; Chomsky 2001; Denemark 2002; Fox 2002; Lizardo and Bergesen 2003; Virilio 2004: 192-197, 235-255; Zizek 200I; see also the contributions collected in Stemplowski 2002). This new strand of terrorism research moves beyond the micro-level focus of earlier research, and takes into account translocal factors (such as those associated with transna-

1. There are of course some important exceptions to this. One wing of terrorism research for instance focused on the study of the international diffusion of terrorism, in particular "spillover" effects of terrorism from unstable to stable areas (such as from the Middle East to Europe in the I970s), which forced them to take a more structural and international perspective. For examples of this line of research see Redlick (I979), Midlarsky et al. (1980), and Pluchinsky (1982, I987). Another notable exception to this micro-bias in terrorism research is an early paper by Crenshaw (I98I) in which she tries to develop a systemic account linking uneven modernization in the periphery and the strains that come with sudden integration into the world economy with local political grievances that express themselves in the form of organized political violence against the state or its representatives. tional political, economic and cultural processes), thus situating the causes and consequences of the types of political violence usually labeled as "terrorism" in a wider structural and historical context. One particular strand of global research on terrorism attempts to connect this phenomenon to other well know secular trends and recurring cycles in the world system, such as the hegemonic sequence (Chase-Dunn 1998) and related global dynamics.

\subsection{The Hegemonic Rise and Decline Model}

Bergesen and Lizardo $(2004,2005)$ for instance, argue that terrorism can be viewed as part of the "systemic chaos" (Arrighi 1994; Arrighi et al. 1999) produced by the unraveling of the post-war civilizing globalization order under conditions of American hegemonic decline. They go on to offer a comparative analysis that situates the current terrorist activity in a global context surprisingly similar to a wave of anarchist terrorist activity that swept Russia, Western and Eastern Europe during the late $19^{\text {th }}$ century when the British hegemonic order was also declining (see also Bergesen and Han 2005 for a general plea toward a more global comparative approach to the study of terrorism). They conclude that waves of transnational terrorism appear to be an effect of comparable largescale global re-ordering processes, having to do with shifting patterns of rivalry and alliance within the core and social and political changes in the semiperiphery as older state formations are destabilized and replaced in favor of alternative sociopolitical arrangements, in the two different historical periods. From this perspective, transnational terrorism appears to be both a trigger and a product of hegemonic decline and the concomitant balkanization of the core produced under a multipolar system (Pollins 1996). From this perspective, anti-hegemonic transnational terrorism first seems to appear in the semiperipheral areas most deeply affected and penetrated by core political and economic interests and later spreads (or "spirals") toward core targets and regions.

Sobek and Braithwaite (2005) develop their own version of an "interstate dominance model" of terrorist activity. They argue, against the hegemonic decline thesis, that we should expect more attacks against the global hegemon as its power increases. They reason that as the international system comes to be dominated by a single global power, transnational actors should shift their attention from less powerful regional hegemons and concentrate their resources against the most powerful actor in the system. Dominance from this point of view leads to an increase in the impact of the hegemon's foreign policy on a wider geographical scale, which may lead to an increase in dissatisfaction with these policies and a more proactive attempt to alter them (i.e. U.s. policy vis-à-vis Latin America or the Middle East). Furthermore, as dominance by a single power increases, the 
perceived effectiveness of non-violent forms of contention is thought to decline, which increases the chances that challenging groups will resort to violent forms. Sobek and Braithwaite (2005) go on to test their dominance model with timeseries data covering the years from 1968 to 1996. Consistent with their dominance account, they find that increasing U.S. dominance leads to an increase in the number of terrorist attacks against American interests. ${ }^{2}$

In this article, I will focus on examining the determinants of a subtype of terrorist phenomena, transnational terrorist attacks against American interests. While Bergesen and Lizardo (2004, 2005) have previously discussed the global antecedents of transnational terrorism in general, they acknowledge that an important component of modern transnational terrorist activity is that which is directed at the hegemonic power itself (Bergesen and Lizardo 2002; Sobek and Braithwaite 2005). The pure hegemonic decline model suffers from the limitation of only speaking to the broad background conditions that open up space for the global incidence of terrorism, but it is silent as to what are the primary mechanisms that intensify or reduce its frequency. For that reason, I turn my attention to two major intervening factors that are considered primary in current global-level accounts: economic globalization and cultural globalization.

Thus, in addition to considering the role of world economic processes in providing a context that may either facilitate or inhibit the expression of violent anti-systemic resistance by subnational groups (which is the dominant factor alluded to by most contemporary accounts), I take seriously the role of world cultural models, recipes and schemas as constitutive of actors, goals and actions (Meyer et al. 1997). I construe these models as also providing a meaningful context for the active expressions of anti-hegemonic expressions of grievances on

2. WhileSobek and Braithwaite's results seem to run counter to the Bergesen-Lizardo hegemonic decline model, there is a strong possibility that this stems from their radically different conceptualizations of American dominance. Bergesen and Lizardo following world systems theory conceptualize dominance in a multidimensional way, resting in economic, cultural and political preponderance (but highlighting the first). According to most of the researchers who measure U.S. hegemony using these political-economic metrics, U.S. dominance has gradually declined in the international system since 1950 (Chase-Dunn et al. 2005). Sobek and Braithwaite on the other hand, conceptualize "dominance" using a simple international influence/rivalry measure which taps the degree to which the U.S. faces a contrarian rival in the United Nations (a powerful nation that consistently votes against the U.S.). Because the capabilities of the U.S.'s most important rival (the Soviet Union) declined during this period, U.S. dominance -according to this measure-appears to have increased during the same span of time, a finding that runs counter to most mainstream accounts of declining U.S. hegemony (see Bergesen and Sonett I999). the global stage. I move beyond traditional considerations of the role of culture in the world system-which see it as either a diffuse ideological smokescreen or as being driven by more fundamental processes associated with global economic flows-by considering the role of a specific form of cultural globalization in shaping patterns of transnational violence. To this end I draw on the world polity tradition of institutional theory (Boli and Thomas 1999), which construes cultural models and abstract forms of knowledge as being given material shape and performative "enactment" in the international system through the increasing structuration of a transnational organizational field composed of non-governmental and inter-governmental associations.

Following this scheme, I divide the current field of global explanations of terrorism into three major categories: (I) "destructive globalization" theories that key in on the negative consequences of economic globalization as producing transnational terrorism, (2) "civilizing globalization" theories that see terrorism as produced by incomplete or uneven globalization, but which generally view economic globalization as dampening international terrorism $(\mathrm{Li}$ and Schaub 2004). Finally, I attempt to articulate and develop (3) a "world polity" approach, which sees anti-U.S. transnational terrorism as partially aided by the diffusion and spread of global schemes of action that go under the rubric of "world culture." Before moving on to considering the global causes of transnational terrorism however, I first define the working conception of terrorism that will be used in the rest of the paper.

\section{DEFINITIONAL ISSUES}

Because in the following I will deal with the much debated issue of terrorism, and sub-state terrorist activity in particular, it is important to acknowledge at the outset that "one person's terrorist is another's freedom fighter" (Ganor 200I), and that state terrorism is both historically prior and has caused much more death and suffering than all historically recorded terrorist acts committed by non-state agents combined (Carr 200I; Chomsky 200I; Oliverio 1998). However beyond these normative concerns, I contend that it is both possible and desirable to arrive at a feasible operational definition of terrorism that (a) avoids most of the pitfalls associated with subjective conceptions of the phenomenon and (b) analytically differentiates non-state terrorism from state terrorism proper. The latter property is desirable in any definition of terrorism because treating terrorism produced by state and non-state organizations as the same type of generic phenomenon may lead to misleading conclusions regarding both its determinants and effects (Goodwin 2004). This is so because state terrorism may be associated with a different set of causal dynamics than non-state terrorism (Bergesen and Lizardo 2005). 
In this respect a lot of the theoretical work on terrorism revolves around definitions (see the discussions in Jenkins 200I; Cooper 200I; Gibbs 1989; Hoffman 1998; Ruby 2002; Schmid and Jongman 1988), but as Jenkins (200I) has noted a quiet consensus appears to be forming on the definition of what constitutes terrorism. For example, for Enders and Sandler "Terrorism is the premeditated use or threat of use of extranormal violence or brutality by subnational groups to obtain a political, religious, or ideological objective through intimidation of a huge audience, usually not directly involved with the policy making that the terrorists seek to influence" (2002: 145-146). The U.S. Department of State defines terrorism as "politically motivated violence perpetrated against noncombatant targets by subnational groups or clandestine agents, usually intended to influence an audience" (quoted in Ruby 2002: 10). This is similar to Chomsky's (2001: 19) definition: "Terrorism is the use of coercive means aimed at populations in an effort to achieve political, religious, or other aims." In line with all of these, from the State Department to Chomsky, is Stern (1999: 30), who defines terrorism as, "an act or threat of violence against non-combatants, with the objective of intimidating or otherwise influencing an audience or audiences." Peter Chalk offers a definition similar to the ones above when he conceptualizes terrorism as "the systematic use of illegitimate violence that is employed by sub-state actors as means of achieving specific political objectives, these goals differing according to the group concerned" (Chalk 1999: 15I). The advantage of this conception is that it leaves open questions of motivation and ideology, which is important when research involves different historical periods and needs to be flexible enough to include such diverse motivations as ethnic separatist ideologies, radical Maoism or fundamentalist Islamic beliefs.

Since the focus of this paper is on transnational terrorism I follow Enders and Sandler (1999) in thinking of transnational terrorism as any act of terrorism which either crosses a politically defined national boundary, or in which organizations or individuals who are citizens of one national entity take as their target objects or persons who are politically affiliated with another national group. Furthermore in this paper I restrict my attention to terrorism produced by subnational groups or organizations who take as their target U.S. related targets or interests. Notice that this is a very different class of phenomena from those usually labeled "state terrorism" which tend to take as their target not U.s. targets and interests (which would constitute a formal act of interstate war against the U.s.) but which are disproportionately directed at the subjugation and control of local populations.
3. GLOBAL ACCOUNTS OF THE ORIGINS OF TRANSNATIONAL TERRORISM

\subsection{The "Destructive" Globalization Thesis}

The destructive globalization thesis is straightforward: recent bouts of antiU.S. terror are a direct result of the ravages caused by the neo-liberal program of globalization of trade and the trans-nationalization of capital (Barber 1995; Chomsky 200I; Hess 2003; Joxe 200I). In other words, terrorism is a reaction from the periphery's disaffected masses against the American-led globalization juggernaut, which destroys local cultures, traditions, and ways of life and replaces them with the alien homogeneity and sterility of American mass culture (Barber 1995; Kellner 2002; Ritzer 2003), while at the same time removing the basis for political and economic sovereignty in the most disaffected areas of the globe (Joxe 200I). Thus modern anti-u.s. terror is the battle cry of a populist "Jihad" against the leveling forces of American globalized popular culture, or "McWorld" (Barber 1992, 1995). ${ }^{3}$

Proponents of the destructive globalization thesis maintain that neo-liberal economic programs subject countries located in the periphery and semiperiphery (Chase-Dunn 1998) to draconian austerity measures that eliminate government protections against the ravages of the open market (Chomsky 1998; Sassen 1998). Some go on to add that the bureaucratization of state structures that result from globalizing processes end up benefiting only a small subset of local elites to the detriment of the marginalized poorer populations (Samiuddin 1997). This causes resentment among the impoverished masses of the periphery, which is then turned outwards to the U.S., which represents the primary source of neo-liberal policies and the primary backers of the transnational organizations charged with their implementation, such as the I.M.F. and the World Bank. Thus, anti-u.s. terrorist attacks can be understood as part of a long-term anti-systemic movement against the most dominant global power from the more dominated fraction of the globe's population (Chomsky 2001; Eisenstein 2002). Transnational terrorism is in this sense primarily a reaction against the twin forces of globalization and American formal and informal imperial domination (Hess 2003; Joxe 200I).

From the destructive globalization point of view, the U.S. is seen by anti-hegemonic actors originating from the world's most disadvantaged areas as both the primary beneficiary of the system of global capital and as its main symbolic presence. This motivates international terrorist organizations to choose targets asso-

3. More general statements of these claims see globalization and terrorism as coterminous and mutually reinforcing processes which are impossible to disentangle (see Baudrillard 200I). 
ciated with the U.S. in order to express their grievances (Campbell 200I). Further, insofar as globalization erodes the basis for democratic institutions in the poorer countries in the world (Li and Reuveny 2003), and due to the persistent post-war U.s. policy of support for non-democratic regimes in the global South in favor of "stability," oppositional groups that initially directed their efforts at local governments may in time shift their attention to the U.S., in an attempt to modify U.S. international policies that are perceived to benefit local power holders (Bergesen and Lizardo 2002). According to this conceptualization, there is nothing distinctive or peculiar about the causes of the recent wave of Arab-Islamic religious terrorism: the very same grievances produced by inequality-generating globalizing processes that spurred terrorist activity by Marxist-inspired groups in LatinAmerica and other parts of the world during the I960s and I970s are sufficient to explain this "new" type of backlash against the West and the U.s. (Kuran 2002; Pasha 2002). Fox (2002: II4) for instance notes that "[fundamentalist] religious terrorism is at least in part a product of the world system... Fundamentalism is a reaction against the modernization process that has dominated the world system for over a century... those who have been hurt or left behind by this process are those more likely to become fundamentalists and, consequently, more likely to become religious terrorists."

While not part of the destructive globalization camp, various experts and commentators that come from a more policy-oriented "counter-terrorist" perspective also perceive economic globalization as contributing to the rise of terrorism (and especially anti-u.s. terrorism) in the last 30 years, albeit through a more indirect route. From this point of view, globalization, insofar as it facilitates the world-wide diffusion and distribution of increasingly technologically-sophisticated communication media, arms, capital, skills and information, can provide non-state actors with the resources and coordination capabilities to engage in campaigns of political violence that had previously remained outside of their logistical purview (Hoffman 1998; Jenkins 200I; Laqueur 1999; Naim 2003). This increased availability of material and coordination resources levels the playing field between larger international actors such as nation-states and smaller non-state entities such as individuals and organizations, allowing the latter to engage in fairly destructive bouts of "asymmetric warfare." As Cronin (2002:30) puts it: "The current [post 1970s] wave of international terrorism, characterized by unpredictable and unprecedented threats from non-state actors, not only is a reaction to globalization but is facilitated by it." Terrorism thus comes to increasingly acquire the character of the "weapon of the weak" allowing disaffected masses to express political discontent by directing attacks at the most powerful actors on the global scene (such as the U.S.).

While the globalization account appears to have acquired a lot of supporters of late, it is hardly new. More than two decades ago, Martha Crenshaw (I98I) had proposed a similar set of hypotheses concerning transnational terrorist activity. She viewed the dislocating effect of world-system economic integration, and the accompanying repercussions related to increasing urbanization in the periphery and widening transnational political and social inequalities as fostering the spread of transnational terrorism. Thus, in many respects the destructive globalization thesis can be seen as an updated version of previous accounts which stressed the role of the demographic, social and infrastructural dislocations produced by national-level modernization projects as a precipitant of terrorist activity. Crenshaw (198I: 380-38I) for instance talks about modernizing forces as producing a set of related factors which function as "permissive" influences on terrorism. These include: $(\mathrm{I})$ increased organization and role complexity at the level of the social structure and the economy; (2) the sudden availability of networks of transportation and communication which offer increased coordination capabilities for small organizations and heighten the impact and scope of violent action displays; and (3) massive and rapid urbanization which results in the agglomeration of large numbers of people in relatively small physical locales making available to terrorist organizations both an increased number of potential recruits and victims and making it harder for authorities to monitor and sanction terrorist activity as it takes the form of "urban guerrilla warfare."

What is new, especially after $9 / \mathrm{II}$, is the connection made between the effects of globalization processes and anti-U.s. sentiment emanating from the popular masses that reside in the world's most economically disadvantaged countries. ${ }^{4}$ As Coker (2002: 7) puts it: "This is one of the paradoxes of globalization. It engenders terrorism: the wish to protect traditional cultures; it creates a sense of powerless for those left on a planet where there is no viable alternative to the orthodoxies of the World Bank. It focuses even more attention on America and 'Americanisation.'" It is important to note that even though the destructive globalization thesis connecting globalization and anti-U.s. terrorism is currently the most prevalent view among most commentators, it has been subjected to little or no empirical attempts at confirmation. For example Li and Schaub (2004) comment that although the weight of existing arguments leans in favor of the positive effect of globalization, little if any consensus has been reached regarding the definite nature of the effect of economic globalization.

4. Notice that what is new is the theoretical connection made by social scientists, and not the presumed operation of this mechanism. Anti-American sentiment was a key ingredient of the Marxist terrorist wave that swept Europe and Latin America during the I960s and I970s. This was of course exacerbated by the bipolar ideological, political and economic rivalry between the former Soviet Union and the U.S. 
This fact notwithstanding, the destructive globalization model leads to a clear-cut expectation:

H1: Economic Globalization is associated with a bigher rate of anti-U.s. terrorist activity.

\subsection{The "Civilizing" Globalization Thesis}

Alternative conceptions of globalization view it as a process associated with the spread of wealth, political and economic freedoms, choice and improved living standards and therefore see the emergence of transnational terrorist activity as a problem that originates from incomplete or uneven globalization across different regions of the world (Friedman 1999). Thus it is a lack of globalization in certain areas of the world and not the ravages caused by the excess of a process best described as a "runaway train" (as is argued for example by Giddens 2002) that is the root cause of most of the grievances expressed by semiperipheral and peripheral actors by way of political violence directed at U.s. hegemony. In addition, defenders of globalization point to a positive correlation between openness to global markets and more democratic and accountable political institutions, a contention that has been supported by some empirical research (more recently Lopez-Cordova and Meissner [2004], but see Li and Reuveny [2003] for empirical evidence to the contrary). ${ }^{5}$

Civilizing globalization theorists argue that once countries begin to open their borders to global economic influences, other transnational influences related to political culture and democratic governance begin to seep through. Thus globalization leads to the creation and transformation of existing civil, economic and political institutions, such as a free press, opposition parties and voluntary

5. The literature on the relationship between democracy and globalization is vast, and continues to grow at an exponential rate, making any attempt to meaningfully review it beyond the scope of this article. Suffice it to say that the majority consensus from most commentators is that globalization may impede the progress of democracy, specifically through its weakening effect on the governance capacity of the nation-state (but see Guillen 200I for a skeptical review of this literature). A smaller, opposing group points to the positive effects that globalization has on democracy, by diffusing liberal culture, supporting individual choice in the market, dissolving localistic and protectionist restrictions, and providing new ideological and technological organizational resources for civil action (Friedman 1999; Fukuyama 1992; McGrew 1997). A third but growing contingent acknowledges that globalization weakens the nation state, and with it standard forms of nationalist liberal democracy, but opens up space for a new form of global "cosmopolitan democracy" (Held 1995). For more in depth considerations of the issue of Globalization and Democracy see McGrew (1997), Munck (2002), Schwartzman (1998), and Scholte (2000). organizations, a process of change that serves to support democratic institutional transformations (Friedman 1999). Because democratization leads to reform at the level of civil society, it opens the political opportunity structure (McAdam et al. 200I) and allows for the organized expression of grievances to be directed to now accountable national government actors. This may help to canalize grievances (even those produced by global economic factors) inward, rather than outward towards the transnational arena, and prevents the "spillover" (Pluchinksy 1987) of terrorism usually produced when autocratic nations attempt to squash internal domestic resistance which ends up forcing domestic terrorist groups outwards toward more hospitable sponsor (or liberal democratic [Wilkinson i986]) states, transforming them into de facto transnational non-state actors.

Furthermore, for civilizing globalization theorists, the most important impact of globalization revolves around what are deemed to be its generally beneficial effects on local economic growth and development. Martin Wolf (2004) for instance, argues that instead of leading to continued impoverishment and economic despair-processes that destructive globalization theorists see as the primary incentives that lead disaffected peripheral populations toward violent action-globalization is instead associated with increasing levels of economic development, a wider variety of material opportunities and increasing chances of social and economic mobility and the attainment of wealth for residents of less economically advanced nations. For Wolf (2002) "Evidence suggests the I980s and I990s were decades of declining global inequality and reductions in the proportion of the world's population in extreme poverty" ${ }^{\prime 6}$ Dollar and Kray (2002) - also proponents of the beneficial effects of globalization on economic development-contend that "higher growth rates in globalizing developing countries have translated into higher incomes for the poor." They note that it is non-globalizing developing countries whose economies have grown at a slower pace, and therefore it is the poor populations in the parts of the global South that are most disconnected from the world economy who are more likely to bear the brunt of global poverty and destitution.

Thus, proponents of the civilizing globalization point of view think of antiU.S. terrorism as a phenomenon that originates when local actors, faced with oppressive local regimes that do little to open up access to globalizing influences, attempt to foster large scale political change through indirect symbolic attacks against prestigious transnational entities. Therefore, peripheral actors that are left-out of the process of global economic integration and who are therefore excluded from the putative benefits associated with open markets are more likely

6. But see Wade (2004) for a critique of the empirical basis of this neo-liberal line of thinking. 
to engage in terrorist violence against U.S. targets. While there is little empirical evidence to support either the destructive globalization or the civilizing accounts of the relationship between transnational terrorism and globalization, a recent study, using cross-national time series data for 1975-1997 on II2 countries, finds support for the notion that the association between transnational terrorism and country-level integration into the world economy is negative, through the indirect positive effect that economic globalization has on economic growth $(\mathrm{Li}$ and Schaub 2004). In sum, the basic expectation that can be gleaned from the civilizing globalization perspective is that terrorism decreases as globalization increases:

\section{H2: Economic globalization is associated with a lower rate of anti-U.s. terrorist} activity.

\subsection{A World Polity Framework}

\subsubsection{The End of History?}

Recent considerations of globalization have begun to move away from strictly political-economic conceptualization of the process and to acknowledge its institutional and cultural aspects (Appadurai 1996; Featherstone 1990; for a review, see Guillen 200I). Researchers who draw on the World-Polity tradition of institutional theory (Meyer et al. 1997; Thomas et al. 1987) propose a framework that views recent globalization trends as including the world-wide spread of cultural schemas, models and forms of knowledge as much as the diffusion of material products and finance capital (Boli and Thomas 1999; Boli and Lechner 2002). These schemas of action and organization are considered part of a rationalized (in the Weberian sense) world culture precisely because they are seen by their proponents as having general applicability regardless of cultural idiosyncrasies and geographical location (Boli and Thomas 1999; Lechner and Boli 2005).

From this perspective, the accelerating post-war global diffusion of cultural models relevant to action in the social, political, economic and natural realms represents the culmination of a move toward global cultural integration that began in the late $\mathrm{I}^{\text {th }}$ century as a part of the colonial expansion of the European powers, but which was interrupted with the eruption of World War I (Boli and Lechner 2002). The principal organizing form that has been responsible for global cultural integration is the nation-state, as the basic legitimized corporate entity of the modern interstate system (Thomas and Meyer 1984). This accounts for its dramatically rapid spread throughout the world system following European decolonization in the I960s (Anderson 1991; Meyer et al 1997; Thomas and Meyer 1984). However, since then, International Non-Governmental Organizations (INGOs) have come to eclipse the state as the primary institutional carriers and diffusers of world cultural models (Boli and Thomas 1999); this has led to their rapid multiplication and spread on a world-wide scale since the rg6os (see figure I).

How can we conceptualize the role of cultural globalization in relation to anti-U.s. terrorism? First it is important to note that the contents of world cultural globalization consist of Western conceptions of the individual, organizations and the role of the state (Meyer and Jepperson 2000). This cultural package is of a primarily liberal-individualistic bent, emphasizing the role of rationality in social and political action and the diffusion of voluntaristic conceptions of individuality that stress the power of organized action at the level of local and global civil-society to produce social change (Boli and Thomas 1999).

One way to interpret this world-wide spread of Western cultural models is by following the somewhat teleological formulations that focus on the "end of history" after the dissolution of communism (Fukuyama 1992). From this point of view, we could construe accelerating cultural globalization trends as resulting in decreased levels of organized anti-systemic resistance (as the world converges around a similar post-ideological culture), and would thus predict that cultural globalization will lead to a decline in anti-u.s. terrorist attacks:

\section{H3: Cultural globalization bas a negative effect on the rate of anti-U.s. terrorist} activity.

\subsubsection{Global Violence and the Constitutive Power of World Culture}

However, this somewhat overly optimistic viewpoint is belied by the postcold-war rise of militant ethno-nationalisms and political fundamentalisms (Friedland 200I). Rather than reaching the end of history after the dissolution of communism as a world ideology, there appears to be an underappreciated continuity in radical anti-systemic action that connects in a direct line the Maoist and radical Marxist struggles of the I960s and I970s to the recent upsurge of radical political religions (Ferguson 200I; Hoffman 1998; Rapoport 1988, 1999, 200I). Following this line of reasoning, I suggest that cultural globalization, especially that having to do with the spread of individualist and voluntaristic models of action, may in fact have a positive effect on the incidence of anti-systemic violence, in contrast to what would be expected from a simple "end of history" model.

This is for two primary reasons: (I) Modern terrorism, since its historical beginnings with Russian anarchism (Joll 1979; Laqueur 1977), has represented the radicalization of voluntaristic, individually-rooted action against encroaching state structures. In this respect, there are many ways in which the post-war diffusion of cultural models that emphasize individual action may actually empower non-state actors to take the responsibility for bringing about rapid social and political change by their own hands. This is consonant with the view 
that explains the rise of modern terrorism in the $19^{\text {th }}$ century as strictly correlative with the diffusion of liberal conceptions of citizenship and legal rights that protect the person from arbitrary government action (Joll 1979; Laqueur 1977; Wilkinson 1986). (2) Because cultural globalization entails the diffusion of cultural models that have their historical origins in Europe and that carry with it specifically Western notions of social and political organization, world cultural diffusion may engender local resistance from certain movements, such as indigenous variants of Maoism or more recent religious nationalisms, that espouse alternative ways of imagining the relationship between the individual and the state and the role of religion in civil society and political governance (Friedland 200I; Juergensmeyer 2000).

These counter-movements, while nominally resisting Western cultural intrusion, may simultaneously feed from its more abstract and constitutive aspects in order to systematize their activities of resistance (Olzak forthcoming). This leads to the apparent paradoxical outcome whereby the very attempt to combat Western cultural diffusion makes use of deep constitutive features of this culture in order to organize that opposition (Friedland 200I; Gray 2003). As Meyer, Boli, Thomas and Ramirez note:

World culture influences nation-states not only at their centers, or only in symbolic ways, but also through direct connections between local actors and world culture. Such connections produce many axes of mobilization for the implementation of world-cultural principles and help account for similarities in mobilization agendas and strategies in highly disparate countries.... Explicit rejection of world-cultural principles sometimes occurs, particularly by nationalist or religious movements whose purported opposition to modernity is seen as a threat to geopolitical stability. While the threat is real enough, the analysis is mistaken because it greatly underestimates the extent to which such movements conform to rationalized models of societal order and purpose. These movements mobilize around principles inscribed in world-cultural scripts, derive their organizing capacity from the legitimacy of these scripts, and edit their supposedly primordial claims to maximize this legitimacy. By and large, they seek an idealized modern community undergoing broad-based social development where citizens (of the right sort) can fully exercise their abstract rights. While they violate some central elements of world-cultural ideology, they nonetheless rely heavily on other elements. For example, religious "fundamentalists" may reject the extreme naturalism of modernity by making individuals accountable to an unchallengeable god, but they nevertheless exhort their people to embrace such key world-cultural elements as nation building, mass schooling, rationalized bealth care, and professionalization... They also are apt to reformulate their religious doctrine in accordance with typical modern conceptions of rational-moral discipline.... In general, nationalist and religious movements intensify isomorphism more than they resist it. (Meyer et al. 1997: 16I, italics added).
This is a feature of recent "reactionary" movements that has been noticed by some analysts (Friedland 200I; Ferguson 200I; Gray 2003; Lizardo and Bergesen 2003) and it is equally applicable to Maoist and Marxist-inspired antisystemic radical movements that dominated the periphery and semiperiphery of the world-system before 1989 (Lizardo and Bergesen 2003). Hoffman (2002: 306-3II) for instance, speaks of Osama bin Laden as a modern day transnational "CEO" who was able to adapt the latest organizational technologies and collective management techniques for the purposes of fashioning a transnational "network organization" bent on fighting against U.s. interests and influence. Gray (2003:3) argues against the view that $\mathrm{Al}$ Qaeda is a "relic of the past" steeped in ancient myths and pre-modern religious traditions. Instead, for Gray (2003:3), "radical Islam is modern. Though it claims to be anti-western, it is shaped as much by western ideology as by Islamic traditions. Like Marxists and neo-liberals, radical Islamists see history as a prelude to a new world. All are convinced they can remake the buman condition. If there is a uniquely modern myth, this is it" (italics added).

Following this lead, I propose a model that views cultural globalization as a factor in facilitating the linkage between the local grievances created by globalizing dynamics and the theorization processes (Strang and Meyer 1993) that allow non-state agents to (a) view themselves as potentially efficacious actors on the global scene and (b) to make the requisite global/local connections that assign specific transnational actors and audiences (such as the U.S or local constituencies.) to their roles in the complex communication structure of the terrorist act. This indirect communication feature of terrorist action is best described in Peter Schmid's definition of terrorism:

An anxiety-inspiring method of repeated violent action, employed by (semi-) clandestine individual, group or state actors, for idiosyncratic, criminal or political reasons, whereby-in contrast to assassination-the direct targets of violence are not the main targets. The immediate buman victims of violence are generally chosen randomly (targets of opportunity) or selectively (representative or symbolic targets) from the target population, and serve as message generators. Threat-and violence-based communication processes between terrorist (organization), (imperiled) victims, and main targets are used to manipulate the main target (audience(s)), turning it into a target of terror, a target of demands, or a target of attention, depending on whether intimidation, coercion or propaganda is primarily sought. (Schmid and Jongman 1988: 28; italics added)

While this relatively complex communicative function of terrorism is not problematic when the originators, targets and secondary audiences of the acts belong to the same local cultural or political context, on the global scene such large scale orchestration of action and meanings is more difficult to establish 
(although given increasingly higher levels of globalization this roadblock should be of diminishing importance). I argue that without the common set of understandings, meanings, and awareness of global roles produced by world cultural integration, this complex process of indirect communication through political violence is difficult to organize and coordinate. Therefore, it is difficult for there to be a conversion of the local grievances produced by globalization processes into the global action that is manifested as direct attempts at political violence against U.S. hegemony without the availability of schemata of action contained in world culture.

Ongoing research by Susan Olzak (forthcoming) finds support for this view. Using longitudinal cross-national data on ethnic episodes of collective violence, she finds that increasing integration into the world polity is positively associated with rates of ethnic mobilization and violence, especially in the periphery and semiperiphery of the world system. She theorizes that cultural globalization allows local actors to articulate their grievances and gain legitimacy for their claims from the larger institutional environment. I propose that a similar dynamic should be expected to obtain in the case of anti-u.s. terrorist activity:

\section{H4: Cultural Globalization bas a positive effect on the rate of anti-U.s. terrorist} activity.

\section{DATA}

\subsection{Dependent Variable}

The dependent variable in the following analyses consists of a yearly count of international terrorist events directed at American targets or "interests" as collected by the State Department; these are broadly characterized as American property or citizens around the world. In order to be included in the series, the event must meet the definition of transnational terrorism described above: terrorist acts committed by domestic actors against American targets are not included in this series. This information has been collected yearly by the State Department since 1968.

I use the portion of the series that covers the 30-year period from 197I-2000; this series has also been described and analyzed by Johnson (200I), Sobek and Braithwaite (2005), Sandler and Enders (2004), and Sandler (2003: 783, table I, [from which the data can be obtained]). ${ }^{7}$ Table i shows a selected sample of the

7. The reader might wonder why I end the series in the year 2000 . The year $200 \mathrm{I}$ is not an outlier in terms of the number of events recorded (2 I9 anti-U.S. attacks occurred in that year, only I9 more than in the previous year) which would make it no a problem to include it in the multivariate analysis. However, the year $200 \mathrm{I}$ is an obvious outlier
Table 1 - Selected Sample of Terrorist Attacks against U.S. Interests Included in the State Department's Annual Count

\begin{tabular}{ll}
\hline Date of Incident & Description \\
\hline May 4, 1973 & $\begin{array}{l}\text { U.S. Consul General in Guadalajara, Mexico Terrance } \\
\text { Leonhardy was kidnapped by members of the People's } \\
\text { Revolutionary Armed Forces. }\end{array}$ \\
August 31,1981 & $\begin{array}{l}\text { The Red Army exploded a bomb at the U.S. Air Force Base at } \\
\text { Ramstein, West Germany. }\end{array}$ \\
April 24, 1987 & $\begin{array}{l}\text { Sixteen U.S. servicemen riding in a Greek Air Force bus near } \\
\text { Athens, Greece were injured in an apparent bombing attack, } \\
\text { carried out by the revolutionary organization known as 17 } \\
\text { November. } \\
\text { The Tupac Amaru Revolutionary Movement bombed the U.S. } \\
\text { Embassy in Lima, Peru }\end{array}$ \\
March 8, 1995 & $\begin{array}{l}\text { Two unidentified gunmen killed two U.S. diplomats and } \\
\text { wounded a third in Karachi, Pakistan. }\end{array}$
\end{tabular}

some of the most "significant" incidents included in this series as reported by the State Department. As can be appreciated from the table, the series errs on the side of inclusion, with attacks directed at both inanimate objects (e.g. buildings) and persons (e.g. ambassadors) included in the series. Further there are attacks perpetrated by both unknown individuals and internationally recognized terrorist organizations (e.g. the German Red Army). Finally the series counts as "U.S. interests or targets" any attack directed at or indirectly involving American civilian, diplomatic, economic or political figures; for more details on this series, see Sobek and Braithwaite (2005) and Sandler and Enders (2004). Attacks on U.S. interests account for a large portion of the number of total events recorded by the U.S. state department even though very few attacks do occur on U.S. soil. Hoffman (1995) also observes that the majority of transnational terrorist attacks in the world take U.s. targets and interests as their focus (Sobek and Braithwaite 2005).

when it comes to the number of deaths and the number wounded. Because I use these supplementary series in the sensitivity analyses reported below I do not include the year $200 \mathrm{I}$ in the analyses reported below. None of the substantive results are changed-the effect of world culture is in fact strengthened-when analyzing the series with the year $200 \mathrm{I}$ included (results available on request). 


\subsection{Independent Variables}

In order to test the above hypotheses I use aggregate world-level data composed of indicator measures of economic globalization, cultural globalization and yearly count data of the number of attacks against U.S. interests for a 30 year period (197I-200I). Globalization data were obtained from an online database maintained by the Global Policy Forum, a non-profit organization affiliated with the United Nations. ${ }^{8}$ I measure trade globalization with two variables. The first variable is equivalent to the total number of regional free-trade agreements in the world for each year of the 30-year time-period under consideration (1970-200I). The second variable equals total world trade as a percentage of Gross World Product (GWP), a measure of the portion of the global economy that is international in nature. These two measures of globalization can be thought of as tapping the more "integrative" aspects of economic globalization that are usually emphasized by the civilizing globalization theorists. However, global economic integration is not the only facet of economic globalization. To this end, I include a financial globalization variable which is measured as total world foreign direct investment (FDI) as a proportion of Gross World Product. This is a measure of the extent and intensity of global capital mobility, monetary flows and currency transfers, which can be considered more closely attuned to the predatory and exploitative aspects of globalization emphasized by destructive globalization accounts. ${ }^{9}$

Finally, following previous research in the world polity tradition (Boli and Thomas 1999) cultural globalization is measured as the total number of International Non-Governmental Organizations (INGOs) that are affiliated

8. These databases can be accessed at http://www.globalpolicy.org. The world trade globalization data (world trade as a percentage of GWP) were obtained from http://www.globalpolicy.org/globaliz/charts/tradepertable.htm. The FDI data come from http://www.globalpolicy.org/globaliz/charts/fdipertable.htm; and the regional trade agreements data can be accessed at http://www.globalpolicy.org/globaliz/charts/ rtatable.htm.

9. A reviewer wondered whether there is a tension across levels of analysis in using global variables to predict terrorist events "which are specific and local." It is important to keep in mind that the terrorist event is not the unit of observation in this analysis. Since the number of yearly anti-U.S. terrorist incidents represent an aggregate across the world, the rate of anti-U.S. terrorism is the dependent variable (Long 1997). The count model assumes that the number of events is a function of this systematic rate and a stochastic disturbance (for the negative binomial model). This rate can be considered a purely global property (since events can occur anywhere in the world and can be carried out by actors hailing from all parts of the globe), and it is thus plausible to think of it as being determined by global-level factors. with the United Nations (Willets 1996). ${ }^{10}$ As Boli and Thomas (1999:6) note, INGOS are "the primary organizational field in which world culture takes structural form." This is because their "primary concern is enacting, codifying, modifying, and propagating world-cultural structures and principles." While Boli and Thomas (1999) concentrate their attention on all INGOs listed with the Union of International Associations, I operationalize the spread of world culture using the more restricted population of INGOs who are formally affiliated with the United Nations. (This population is in general smaller, but is also better able to track the growing global legitimacy of world cultural precepts, insofar as the U.N. constitutes the primary non-state actor on the global scene.) The data that I use includes three types of INGOs: (I) "General Status" INGOs which are "global, large membership and work on many issues"; (2) "Special Status" INGOs that are "regional and general or specialist and high status"; and (3) "Roster" INGOs which are smaller and "highly specialist" organizations who work in close cooperation with U.N. agencies. ${ }^{11}$

\subsection{Control Variables}

I include three control variables associated with the composition of the interstate system and the foreign policy and international conflict environment that might affect the rate of terrorist activity: First I employ a period effect dummy variable for the post cold war period (1989-2002) in order to take into account the transition from the bipolar cold war international order to the unipolar postcold-war arrangement (Pollins 1996: 2). Secondly I control for the total number of states in the system, as the opportunity structure of sponsorship, and the dynam-

10. These data were obtained from the online database maintained by Peter Willets at http://www.staff.city.ac.uk/p.willetts/NGOS/NGO-GRPH.HsTM\#data.

11. A reviewer noted that since terrorist organizations are themselves transnational NGOs, using INGO density as predictor of the rate of anti-U.s. terrorism may not be appropriate since terrorist organizations are "just another INGO, growing with the rest of them." While this comment is suggestive, I follow Tarrow (2004: I2) in analytically and empirically differentiating organizations whose primary behavioral script is non-violent (or non-contentious), and those which are primarily formed to produce contentious and/or violent actions against states or other actors. In this sense INGOs are radically different from transnational social movement organizations or terrorist actors, in that even though they may share similar ideologies, "...the main distinction between INGOs and social movements becomes primarily behavioral. Although both may have social change goals, transnational social movements engage in sustained contentious interaction with states, multinational actors, or international institutions, whereas INGos engage in routine transactions with the same kinds of actors and provide services to citizens of other states." 
ics associated with ethno-nationalist and separatist struggles associated with the proliferation of the nation-state form may affect the rate of terrorism (Hoffman 1998). ${ }^{12}$ Finally in order to adjust for the possible inciting effect of u.s. military interventions across the world, I include a variable equal to the number of militarized interstate disputes (MIDs) involving the U.s. for that year. ${ }^{13}$ This "blowback" hypothesis has recently been popularized by political scientist Chalmers Johnson. According to Johnson (2003) terrorist activity is in large part motivated by U.S. military operations around the world, which serve to support reactionary and sometimes oppressive domestic governments. Terrorist groups then direct their activity toward U.S. targets as an attempt to avenge what they see as unlawful and illegitimate interference and support of foreign U.S. economic and political interests in their focal region. In this manner, Johnson conceives of contemporary terrorism as the unintended side-effect of U.S. imperial military adventures across the globe (Johnson 2003: xv-xxii).

All variables mentioned above are differenced one time-step to remove secular trends; that is, instead of using the value $X_{t}$ of I use the value of $\left(X_{t}-X_{t-1}\right)$. Figure I shows the yearly distribution of the variables used in the analysis.

\section{METHODS}

\subsection{Negative Binomial Models for Counts}

Because the dependent variable consists of annual event counts-meaning that the dependent variable is always positive and cannot take a value below zero-I use a general linear model (Hardin and Hilbe 200I) in which the expected count is assumed to come from a negative binomial distribution with the systematic part of this process (which is a linear function of the predictors) "linked" to the expected by way of a logarithmic function to ensure exclusively positive predictions. Modeling the expected count as coming from a negative binomial distribution is appropriate here because in contrast to the simple Poisson model (which is a common model for count data), which assumes equal mean and variance in the counts, the negative binomial distribution is more flexible in that it relaxes this somewhat restrictive assumption. This is important since most empirical counts-such as the one of interest here-are characterized by either underdispersion (variance is smaller than the mean) or overdispersion (variance is

12. These date come from the Correlates of War Project Interstate system membership file (Correlates of War Project 2005).

13. These data were obtained from version 3.02 of the Militarized Interstate Dispute data set (Ghosn and Bennett 2003)
Figure 1 - Autocorrelation Function Plot of the Attacks Series

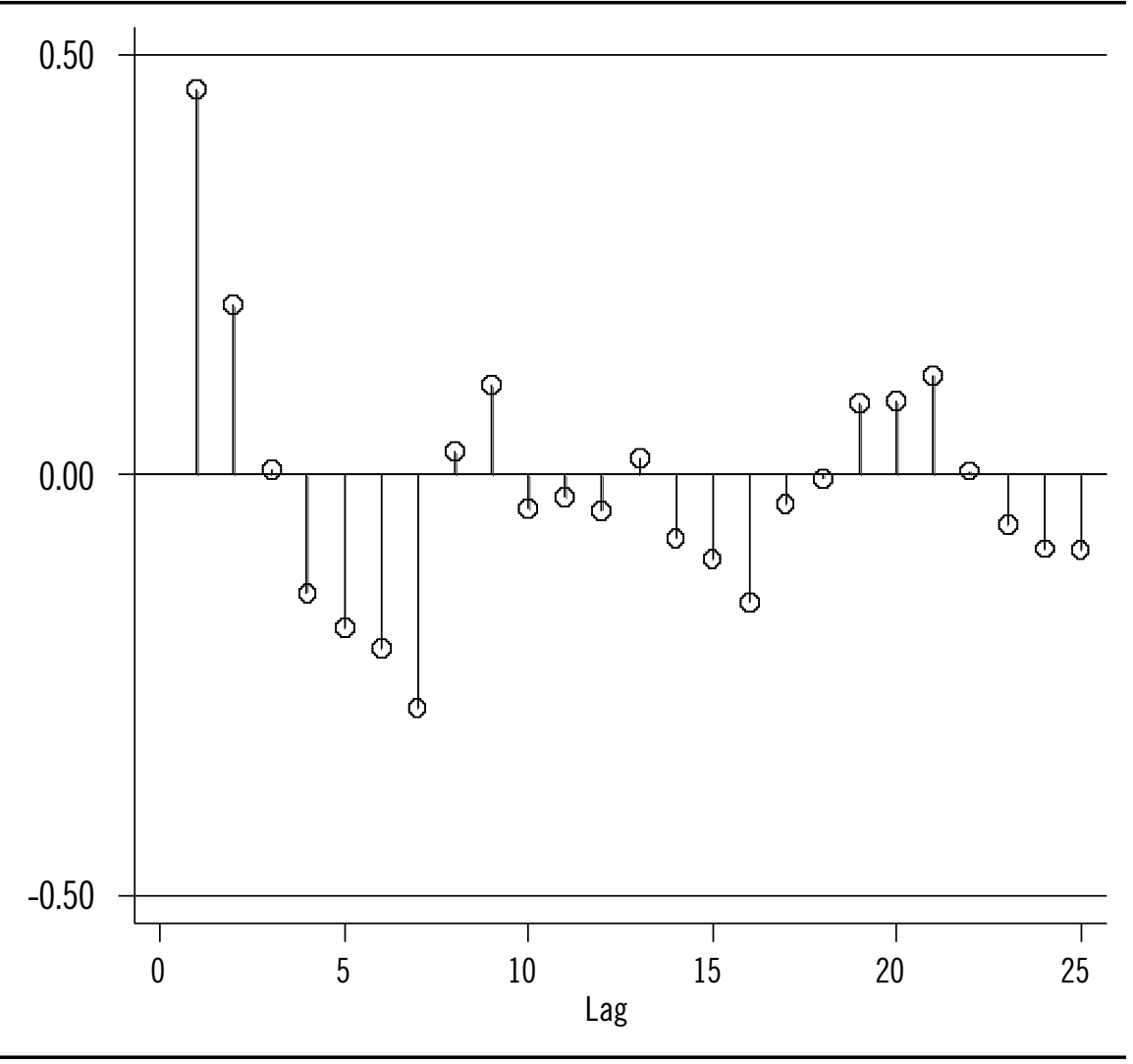

Bartlett's formula for MA(q) $95 \%$ confidence bands

larger than the mean), which makes the negative binomial model a more realistic choice than the Poisson model (Long I997). ${ }^{14}$

\subsection{Accounting for Autocorrelation}

With time series data the dependence of the count in a given year on the value of the dependent variable on the year before (usually referred to as autocorrelation) is always a concern. This may motivate the usage of models which take

14. The attacks series under consideration here is extremely underdispersed with a mean of 162.6 and a standard deviation of 48.5 , which means that the expected value is about 3.3 times larger than the dispersion. 
into account more complex patterns of time-dependence such as autoregressive integrated moving average (ARIMA) models, it has been shown that negative binomial count models that include a lagged dependent variable do a good job of accounting for time-dependence whenever the structure of this dependence is no more complex than a simple autoregressive (ARI) process (Hannan I99I; Barron 1992). ${ }^{15}$ Previous examinations of the series used here (namely Sobek and Braithwaite 2005) have shown that this is indeed the case with these data. In order to verify this assumption, figure I shows the auto correlation function (ACF) diagram for this series. The vertical length of the lines indicates the magnitude of the correlation of the count at that period with the count at the preceding time period, and the horizontal bands point to the $95 \%$ confidence interval. As suspected, only the first lag appears to be significant within conventional levels. While there appear to be some slight negative autocorrelation at the $5^{\text {th }}$ and $6^{\text {th }}$ lags, the magnitude of the effects do not appear to be substantial. Consequently, I will limit myself to the presentation of NBR models with a lagged dependent variable and dispense with the use of more elaborate ARIMA specifications.

\subsection{Non-Independence of the Error Terms}

GLMs, like other linear models, work under the assumption that the errors are independent (the homoskedasticity assumption). However, with time series data this assumption seldom obtains, since in each year some number of unmeasured events that affected the dependent variable in previous periods may have an impact on the focal period, producing some non-trivial degree of correlation between the contemporaneous error term and those that belong to previous years. Furthermore, the effects of these random "shocks" may survive (in a weaker form) beyond a single lag up to an unknown span. One way around this problem is to impose some parametric function on the error correlation (a "moving average" model); another option is to dispense with the error independence assumption without attempting to specify the form of the correlation using the well-known "robust" estimator of the error-variance. For time series models, it is possible to specify an unstructured auto-correlation of the error terms up to some lag selected by the analyst, a technique recommended by Newey and West (1987). I opt for this last approach here. Thus, all models presented below are calculated using Newey-West heteroskedasticity and autocorrelation consistent (HAC) estimator of the variance up to eight lags (increasing the number of lags

15. An autoregressive process is defined as a correlation (negative or positive) between the count at time $t$ and the count at time $t-n$ where $n$ is the time period (first, second, third, etc.) preceding it. Thus an autoregressive process of order I entails a correlation between the count at some time period and the count at the preceding period.

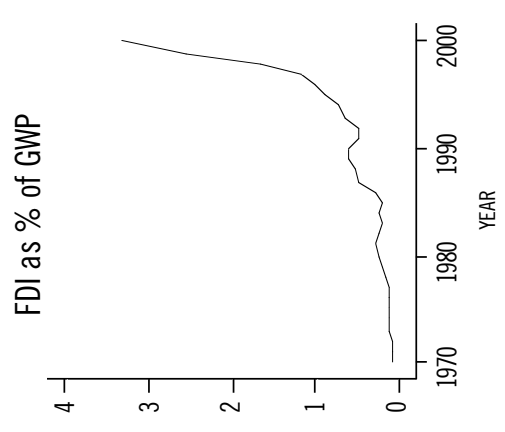

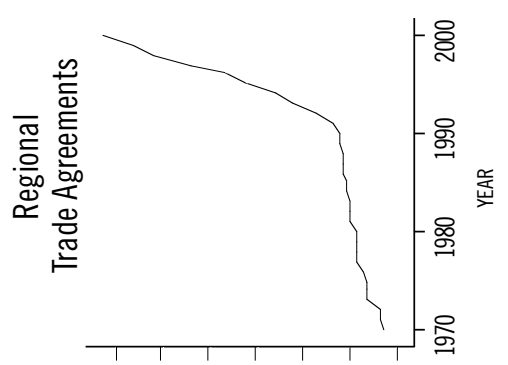

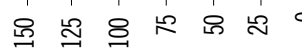
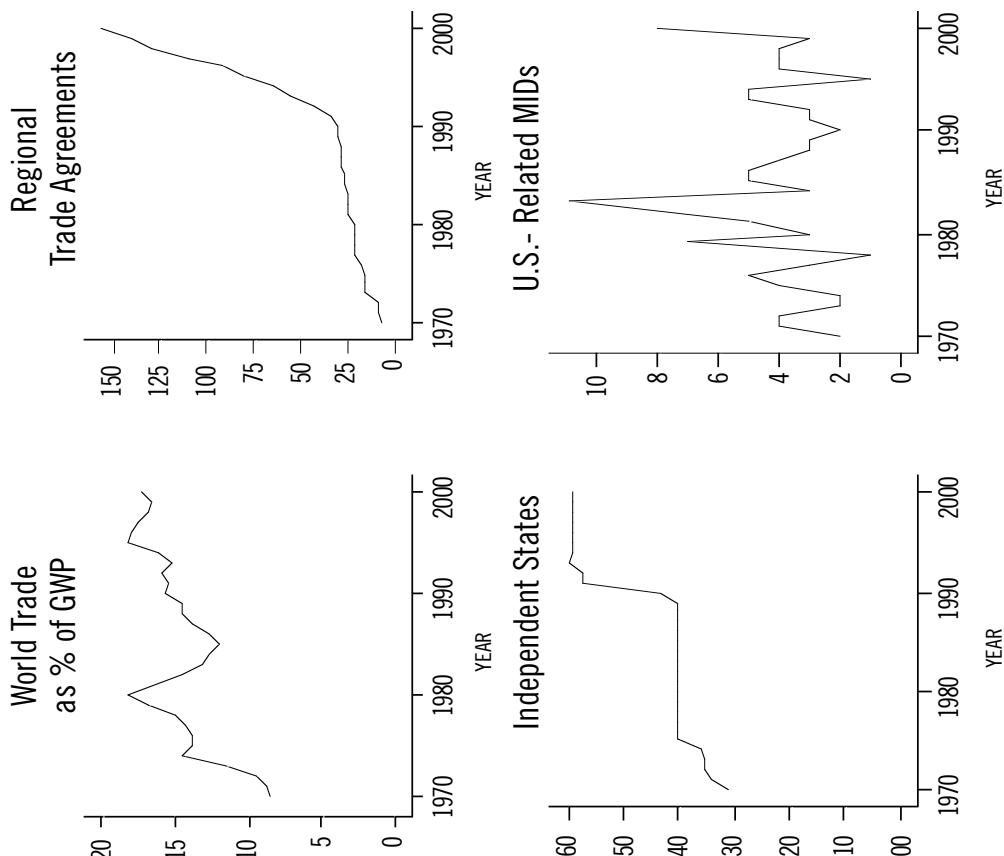

\&
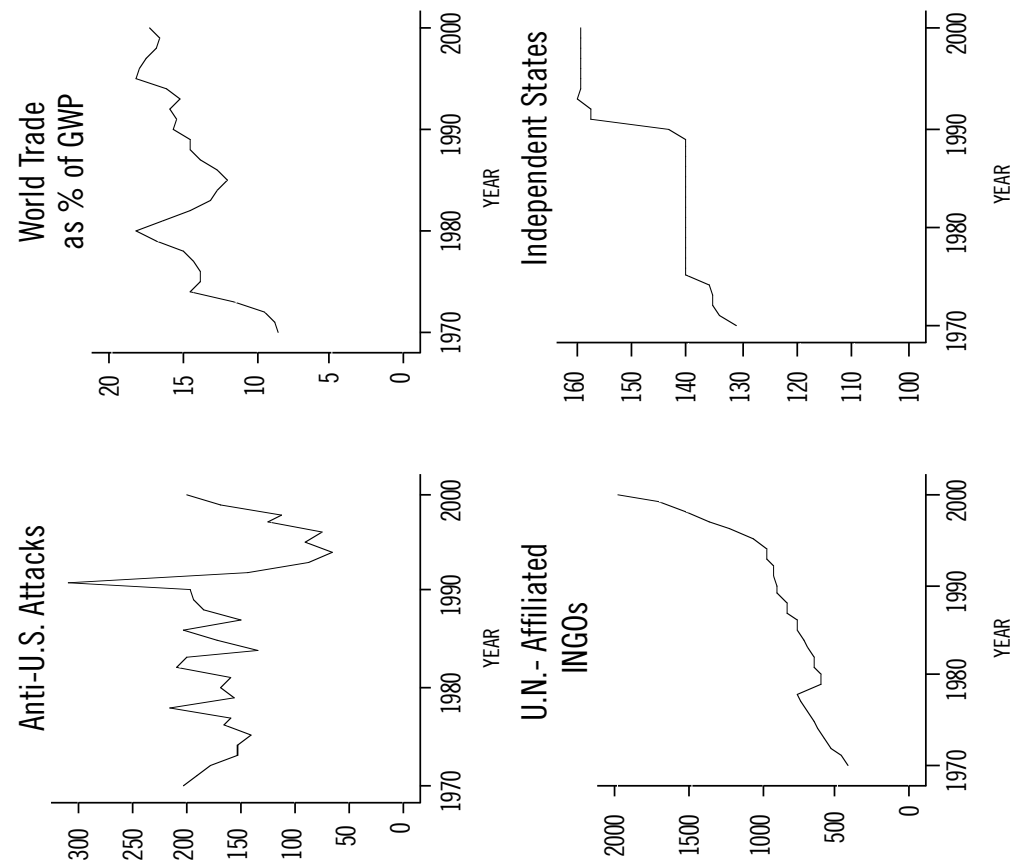
do not change the results). Since this type of "robust" estimation precludes model comparison by way of traditional likelihood-ratio tests, I present other measures of model fit: the model deviance statistic (with smaller values indicating a better fit) and an r-squared statistic designed for GLMs (Zheng and Agresti 2000). This pseudo R-squared statistic is simply the zero-order correlation between the fitted response and the observed response values.

\section{RESULTS}

Table 2 presents the results of four models showing the effects of world economic and cultural globalization on the number of terrorist acts directed at U.S. interests for the period of 1970-200I. Each model includes a lagged version of the dependent variable as a current predictor of its values in order to account for first-order autoregression effects. I tested specifications that included higher order (second and third) autoregression coefficients, but no lag of order higher than one proved to be significant. This is consistent with results obtained by Sobek and Braithwaite (2005) using the same series, and with the ACF diagram shown in figure $\mathrm{I}$.

\subsection{A Baseline Model}

Model I is a baseline model in which the dependent variable is regressed against its lagged counterpart in the preceding period; improved model fit can then be gauged with decreases in the model deviance statistic and increases in the R-squared statistics in comparison to this model. The baseline model shows that as expected, an autocorrelation effect of order one is present in the data $(t=5.23)$, accounting for about $15 \%$ of the variance. This autocorrelation effect is-as should be expected-positive and significant, suggesting that, as shown in previous research (see Enders and Sandler 1999; also Midlarsky et al. 1980), a higher rate of activity in a previous period serves to encourage further terrorist activity in future periods (i.e. a "contagion" effect).

Model 2 introduces the three control variables, the cold war period variable, the number of states in the international system, and the number of U.S.-related militarized interstate disputes. The introduction of these variables significantly improves the fit of the model, with the R-squared more than tripling (going from 0.15 to 0.52 ). The post cold war period effect variable has a negative and statistically significant effect on the number of terrorist attacks against U.S. targets $(t=-2.18)$, while the effect of the size of the interstate system is positive and also significant $(t=3.01)$. The "blowback" effect on the other hand, while in the expected
Table 2 - Negative Binomial GLMs Regression Coefficients of the Global Predictors of the Number of Terrorist Attacks against U.S. Interests, 1970-2001

\begin{tabular}{|c|c|c|c|c|}
\hline & Model 1 & Model 2 & Model 3 & Model 4 \\
\hline \multirow[t]{2}{*}{ Lagged N. of Attacks } & $0.0037^{*}$ & $0.0020^{*}$ & $0.0018^{*}$ & $0.0019^{*}$ \\
\hline & $(5.23)$ & $(3.01)$ & $(2.43)$ & $(2.57)$ \\
\hline \multirow[t]{2}{*}{ N. of States } & & $0.0488^{*}$ & $0.0610^{*}$ & $0.0562^{*}$ \\
\hline & & $(3.12)$ & $(3.92)$ & $(3.31)$ \\
\hline \multirow[t]{2}{*}{ Cold War } & & $-0.2546^{*}$ & -0.2712 & -0.2404 \\
\hline & & $(-2.18)$ & $(-1.82)$ & $(-1.54)$ \\
\hline \multirow[t]{2}{*}{ Number of MIDs Involving U.S. } & & 0.0091 & -0.0010 & 0.0006 \\
\hline & & $(0.65)$ & $(-0.05)$ & $(0.04)$ \\
\hline \multirow[t]{2}{*}{ World Trade as $\%$ of GWP } & & & $-0.0328^{*}$ & $-0.0266^{*}$ \\
\hline & & & $(-3.01)$ & $(-3.00)$ \\
\hline \multirow[t]{2}{*}{ N. of Regional Trade Agreements } & & & -0.0187 & -0.0230 \\
\hline & & & $(-1.54)$ & $(-1.81)$ \\
\hline \multirow[t]{2}{*}{ FDI as $\%$ of GWP } & & & $0.7260^{*}$ & $0.5547^{*}$ \\
\hline & & & $(5.70)$ & $(4.25)$ \\
\hline \multirow[t]{2}{*}{ N. of U.N. Affiliated INGOs/1000 } & & & & $0.7732^{*}$ \\
\hline & & & & $(2.45)$ \\
\hline Model deviance & 2.19 & 1.55 & 1.08 & 1.05 \\
\hline Pseudo R-Squared & 0.15 & 0.52 & 0.63 & 0.64 \\
\hline $\mathrm{N}$ & 30 & 30 & 30 & 30 \\
\hline
\end{tabular}

${ }^{*} \mathrm{p}<0.05$ ( $\mathrm{t}$-statistics in parentheses)

positive direction, is not statistically distinguishable from zero $(t=0.65) \cdot{ }^{16}$ The positive effect of the number of states in the international system is consistent

16. Exploratory models show that a bivariate model including only the blowback effect reveals a sizable and statistically significant positive effect $(t=2.69)$ of U.S. related MIDs on the rate of anti-U.S. terrorist activity as predicted by the blowback thesis. The blowback effect disappears, however, once we introduce a control for the rate of terrorist activity at time $\mathrm{t}-\mathrm{I}$. This suggests that the positive correlation between U.S. military interventions and terrorist attacks is spurious, since both appear to be driven by previous levels of terrorist activity (a possibility that Johnson [2003] himself acknowledges as consistent with a "baiting" strategy by terrorist groups). Using lagged values (up to ten years) of levels of U.S. military interventions in other countries - to allow time for U.S.-created grievances to "simmer"-does not change the pattern of results. 
with previous claims regarding the facilitating influence that the proliferation of weak states in the periphery and semiperiphery of the world system, especially after the I960s, has had on transnational terrorist activity (Hoffman I998; Jenkins 200I). The negative sign of the cold war dummy supports the contention that the rate of anti-U.s. terrorism has been on the decline since its heyday in the late I970s and early I980s (Enders and Sandler 1999; Johnson 200I) even though the actual letbality of the attacks is on the rise (this is also visually evident in the attack series as shown in figure I).

\subsection{The Effects of Economic Globalization}

Model 3 is the simple "economic globalization" model which includes the number of free-trade agreements, world trade as a percentage of gross world product and financial globalization in the form of FDI as a percentage of GWP. Both the deviance statistic and the R-squared measure of predictive power show that the inclusion of these variables substantially improves model fit. The model deviance is decreased by $31 \%$ and the R-squared measure increases from $52 \%$ to $63 \%$ percent, suggesting that economic globalization plays an important role in determining anti-U.s. terrorist action. The direction of world trade coefficients offers some solid support for civilizing globalization claims, and some mixed support for the destructive globalization model. In contradiction to expectations derived from the destructive globalization perspective (hypothesis I) and as would be expected given the civilizing globalization point of view (hypothesis 2), economic globalization (higher rates of international trade and economic integration through trade agreements) appears to have a negative association with the rate of anti-U.S. terrorism, although the negative effect of the trade agreement measure does not reach standard levels of statistical significance $(t=1.54)$. The overall level of world trade as a percentage of total world production on the other hand has a strong negative association with anti-u.s. terrorism $(t=-3.01)$. These effects are consistent with the results reported in $\mathrm{Li}$ and $\mathrm{Schaub}$ (2004), who find evidence that the negative impact of integrative economic globalization is indirect because it is mediated by economic growth. Notice also that after taking into account the economic globalization effects, the negative effect of the cold war period variable disappears, suggesting the post 1989 decline in anti-u.s. transnational terrorism is completely accounted for by world economic conditions.

In accordance with destructive globalization accounts however, the economic globalization variable that most directly taps the extent to which the poorer countries are exploited in international economic arrangements-by way of increasing capital mobility and the creation of financial dependent relations-foreign direct investment as a percentage of the total world economy is positively associated with
Figure 3 - Plot of the Attacks Series Against the Differenced Foreign Investment and INGO Series
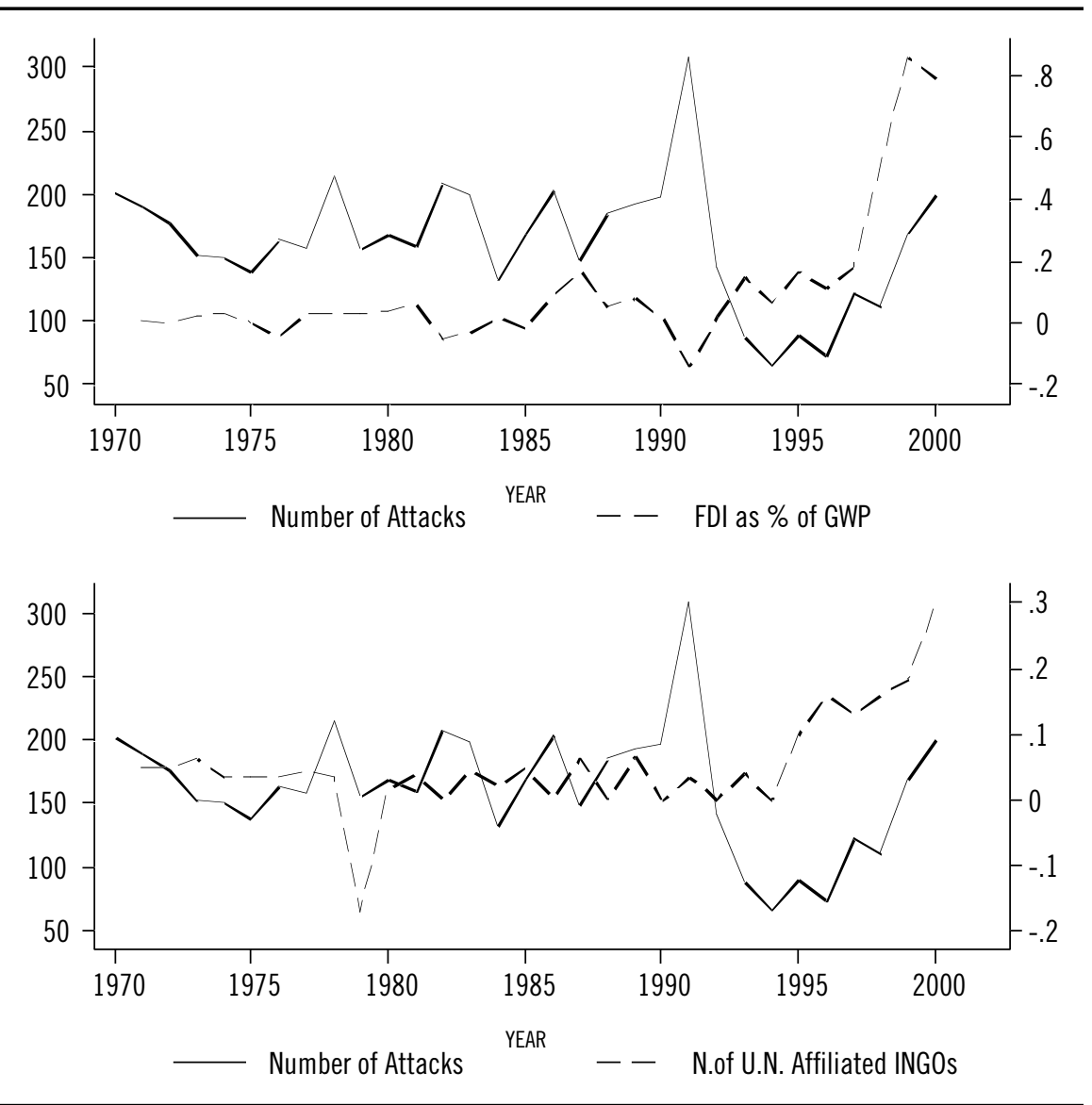

the rate of terrorist attacks against the U.s. $(t=5.70)$. The upper panel of figure 3 shows the joint plot of the differenced financial globalization variable and the number of attacks against time. After 1990, these two series track each other surprisingly well, with the post-Cold War recovery in anti-U.s. terrorism coinciding with the exponential growth in global financial flows during the I99os. This suggests that the intensification of finance capitalism towards the end of the century-a development which Arrighi (2005:88) refers to as the "Belle Époque" of American hegemonic decline-may have served to intensify and give life to a new ("fourth") wave of anti-hegemonic resistance by non-state terrorist groups, 
providing a possible mechanism linking transnational terrorism and hegemonic decline (Bergesen and Lizardo 2005).

\subsection{The Effects of Cultural Globalization}

Model 4 is a "cultural globalization" model which includes the measure of world cultural diffusion. In accordance with the world polity account (hypothesis 4), cultural globalization is in fact associated with bigher and not lower (as predicted by (hypothesis 3 ) levels of anti-u.s. terrorist activity $(t=2.45)$. The inclusion of this coefficient improves the fit of the model, according to both the deviance and the R-squared criteria. Looking at the economic globalization coefficients in model 4, we can see that cultural globalization appears to partially mediate the negative effect of world economic integration through trade (which is reduced by about $19 \%$ ) and the positive-effect of financial globalization (which is decreased by more than a fifth [23\%] with the inclusion of the cultural globalization effect). Thus cultural globalization appears to be an important mechanism linking world trade integration to lower rates of terrorist activity.

As can be observed in the lower panel of figure 3, the growth of INGOs had been in a rather flat state since the I970s (except for a dip in the late 1970s), but has accelerated since the early I990s. Notice that the recent recovery of transnational terrorist attacks against the U.s. is closely synchronized with the post 1989 acceleration in the growth of transnational organizations in global civil society. The cultural globalization series is similar to the financial globalization series in that both seem to do a good job of accounting for the post-cold war recovery of anti-U.S. terrorism (although as shown in model 3 both have a net effect even when holding the other constant). In all, the positive effect of cultural globalization is in stark contrast from what we would expect given an "end of history" account, but is compatible with an alternative model of the process, which views the globalization of cultural models as a facilitator of transnational anti-systemic action.

\subsection{Sensitivity Checks}

As a sensitivity check on these results, I fit a model with the same specifcation as in model 4 of table 3 , this time using the number of terrorist attacks reported by the state department that did not include U.s. targets or interests. ${ }^{17} \mathrm{I}$ repeat the same procedure with a third and a fourth series: the total number of deaths and the number of individuals wounded (not shown). None of the economic or cultural globalization variables that were significant predictors of anti-

\footnotetext{
17. These results are available upon request.
}

U.S. terrorist attacks in table 2 reach statistical significance in these models. The only exception appears to be financial globalization, which has a positive impact on the number of deaths. This result is consistent with the fact that the financial globalization series picks up after the cold war, the same period in which the "new" (deadlier) terrorist wave comes to the fore. The fact that none of these alternative series is adequately predicted by the globalization variables is a good indication that the U.S.-related events series is more systematic (and therefore connected to global economic and cultural currents) than the non-u.s., death and wounded series. In all probability this is due to the fact that the former series is much closer to the total population of events, given that (a) this population is smaller and (b) that it was collected by the U.S. State Department; and the good fit of the previous four models shows that this systematic component of the antiU.s. attacks series is well accounted for by the predictors.

\section{DISCUSSION AND CONCLUSION}

The above results provide strong evidence for an alternative way of conceptualizing the association between economic globalization, cultural globalization and transnational terrorism. Purely economistic perspectives of either a civilizing globalization or destructive globalization bent, point to either the enabling or constraining role of globalization processes of an exclusively economic nature on organized political violence against representatives of the dominant order. In this paper, I introduce the role of cultural globalization, and in particular the type of cultural globalization that carries with it modern institutionalized conceptions of individuality, organization and social action (Meyer et al. 1997), as a key mechanism that enables actors to form a link between the local grievances caused transnational capital flows and transnational action directed against U.s. hegemonic power. The results show that both the negative effects of economic trade integration pointed to by civilizing globalization accounts and the positive effects of financial globalization isolated by the destructive globalization camp are partly mediated by the effect of cultural globalization.

From this perspective, the post-wwir globalization of cultural models and recipes for action is seen as having the unintended effect of serving as an empowering resource for affected populations that endows them with the capacity to see themselves as efficacious actors successfully engaging in anti-systemic battles against the dominant powers in the global arena. In this vein, it is tempting to speculate if previous bouts of terrorist activity in the recent historical past, such as the anarchist wave that swept Europe during the last half of the $19^{\text {th }}$ century (Bergesen and Lizardo 2004) was also enabled by the then rising level of integration of the world polity. Suggestively, both the $19^{\text {th }}$ century terrorist wave and 
first wave of world cultural diffusion would go on to be interrupted at about the same time by the outbreak of World War I (Boli and Lechner 2002; Rapoport 200I).

In this respect, it is important to note that the destructive globalization thesis, which points to a direct link between some forms of economic globalization and anti-systemic reaction in the form of anti-U.s. terrorism, does not receive unqualified empirical support in the present analysis. It appears that trade globalization has a constraining effect on expressions of anti-u.s. political violence, as would be expected from the point of view of civilizing globalization perspectives that understand increasing world integration through trade and transnational capital flows as producing gains in wealth and quality of life that defuse the motivation for anti-systemic political violence. However, the form of globalization which is most predatory, that measured by financial globalization in the form of transnational capital flows as a proportion of the world economy, does have a positive association with anti-U.s. terrorism, supporting the contention that local grievances caused by inequality-fostering mechanisms in the international economic arena are at lest partially responsible for recurring bouts of anti-u.s. transnational violent action.

Thus it appears that the incompleteness of the most generalist destructive globalization and civilizing globalization accounts is ultimately related both to their reflexive equation of high-levels of globalization with high-levels of antisystemic action and vice versa, and to their exclusion of other globalizing processes beyond those related to economic factors. This is related to the inability of both destructive globalization and civilizing globalization theorists to distinguish between different forms of economic integration and economic penetration (Kentor and Boswell 2003), that may be mixed in most outcomes of interest. The results reported here suggest that both the sanguine and fatalistic accounts of the effects of economic globalization espoused by civilizing globalization and destructive globalization perspectives respectively, are too simplistic. Economic globalization is a multifaceted process, and as such is both a constraining and enabling force for transnational political violence in the global forum.

An important contribution of this article has to do with both establishing the role of a specific form of cultural globalization in affecting patterns of radical political action in the transnational arena, and with showing that its effects hold net of the standard factors associated with material exchanges at the global level. Thus, I show that cultural globalization in the form of the spread of international organizations which serve as institutional carriers of global models for action, has a strong positive impact on the rate of anti-U.s. terrorist activity. This is expected given a model that sees political action as not only motivated by rationalistic and instrumental goals (such as material deprivation and other local grievances [i.e.
Gurr 1970]) but also constituted and facilitated by transposable schemas of perception, action and organization that diffuse throughout the global field (Olzak forthcoming; Hironaka 2005).

In this sense the anti-systemic global action of local terrorist groups while certainly spurred by the grievances produced by growing levels of inequality and material deprivation throughout the globe, must also wait for the diffusion of the forms of knowledge necessary to situate those grievances in their proper transnational context to become available. These in their turn serve to widen the "political event horizon" of local non-state actors with limited indigenous opportunities for grievance-expression to include transnational audiences, or to use transnational actors as an indirect link in the complex communication chain of the terrorist act (Schmid and Jongman 1988). Cultural globalization may also make possible the development and diffusion of transnational collective identities (e.g. Pan-Slavism in the $19^{\text {th }}$ century; or Pan-Indigenism in Latin America today) that facilitate cooperation, the establishment and maintenance of networks of trust (Tilly 2004) and the coordination of action between non-state actors located in different national, ethnic and geographical contexts.

This analysis also moves beyond theoretically impoverished conceptions of terrorists as rational-calculative actors couched in the language of methodological individualism and game theory (see Sandler and Arce 2003; Sandler and Enders 2004) by emphasizing the constitutive and interpretive basis for action that leads to political violence and by paying attention to processes that occur at a purely global level of analysis (Bergesen and Lizardo 2002). I focus on culture without resorting to the anti-rationalist reaction of viewing terrorism as a throwback to "medieval" or "primordial" cultural modes of organization and thinking. This latter account is as incapable as unrealistic game-theoretic models of explaining the fact that it has been the spread of a modern, rationalized and Western global culture that is associated with a rise in anti-u.s. terrorism during the past 30 years (Gray 2003). While models that focus on lower levels of analysis have made important contributions to the study of terrorism (see Crenshaw 1992 and Bergesen and Lizardo 2004 for a review), the fact that transnational political violence has become a global phenomenon necessitates a shift in perspective toward a more encompassing global level of analysis (Bergesen and Lizardo 2005).

The present account also differs from other macro-level accounts of the influence of culture on global conflict by moving beyond mechanical and simplistic neo-conservative descriptions of a "clash of civilizations" or neo-Hegelian homogenizing teleological accounts of the "end of history". Thus, In contrast to Huntington (1997) I consider not the ultimate incompatibility between Western and non-Western cultural models as contributing to the rise of radical modes of political violence, but see modern terrorism as an inherently modern phenomenon, 
"a facet of modern politics" and "principally associated with the rise of nationalism, anarchism and revolutionary socialism" (Crenshaw 198I: 380). From this perspective, transnational terrorism is inseparable from Western cultural models that are the ultimate building blocks of rationalized modes of the individual and social action (Weber 1946), including "rational" action. It is in this sense that modern terrorism has more in common with modern anarchism (Ferguson 200I; Lizardo and Bergesen 2003) than with a return to medieval obscurantism or primordialist "Islamo-fascism." In opposition to Fukuyama (1992) this view of the enabling powers of Western cultural schemas even in regard to actions that are putatively against most of what the West stands for does not excise conflict from the current historical juncture. Instead, as Friedland (200I) has noted, this perspective acknowledges that cultural battles regarding the role of the individual, the state and civil society but fought within the framework of the modern conception of the politics of nationalism and even the contradictory ideological role of individualism in anti-systemic action will be a recurring feature of the transnational arena for years to come.

\section{REFERENCES}

Anderson, Benedict. I99I. Imagined Communities. Revised second edition. New York: Verso.

Appadurai, Arjun. 1996. Modernity at Large: Cultural Dimensions of Globalization. Minneapolis, MN: University of Minnesota Press.

Arrighi, Giovanni, 1994. The Long Twentieth Century: Money, Power and the Origins of Our Time. London: Verso.

83-II6.

Arrighi, Giovanni, Beverly J. Silver, and others. 1999. Chaos and Governance in the Modern World System. Minneapolis, MN: University of Minnesota Press.

Barber, Benjamin. I992. "Jihad vs. McWorld." The Atlantic Online. Last accessed

February I, 2003: http://www.theatlantic.com/politics/foreign/barberf.htm. - I995. Jibad vs. McWorld. New York: Times Books.

Barron, David N. I992. "The Analysis of Count Data: Overdispersion and Autocorrelation." Sociological Methodology 22: 179-220.

Baudrillard, Jean. 200I. "The Spirit of Terrorism." Le Monde November 2. Bergesen, Albert J., and Omar Lizardo. 2002. "Terrorism and World System

Theory." pp. 9-22 In Transnational Terrorism in the World System Perspective, edited by Ryszard Stemplowski. Warsaw: The Polish Institute of International Affairs. -- - 2004. "International Terrorism and the World System." Sociological Theory $22: 38-52$.
---_---. 2005. “Terrorism and Hegemonic Decline." Pp. 227-240 in Hegemonic

Decline: Present and Past, edited by Jonathan Friedman and Christopher ChaseDunn. Boulder, CO: Paradigm Publishers.

Bergesen, Albert J., and Yi Han. 2005. "New Directions for Terrorism Research." International Journal of Comparative Sociology 46: I33-I5I.

Bergesen, Albert. J., and John Sonnett. 2001. "The Global 500: Mapping the World Economy at Century's End." American Behavioral Scientist 44: 1602-1615.

Boli, John, and Frank J. Lechner. 2002. "Globalization and World Culture.” In International Encyclopedia of the Social and Behavioral Sciences. Amsterdam: Elsevier.

Boli John, and George M. Thomas. 1999. Constructing World Culture: International Nongovernmental Organizations since 1875. Stanford, CA: Stanford University Press.

Campbell, Kurt M. 2002. "Globalization's First War?" Washington Quarterly 25ः 7-I4. Carr, Caleb. 200I. The Lessons of Terror. New York: Random House.

Chalk, Peter. 1999. "The Evolving Dynamic of Terrorism in the I990s." Australian Institute of International Affairs 53: 15I-167.

Chase-Dunn, Christopher. 1998. Global Formation: Structures of the World-Economy. Lanham, MD: Rowman and Littlefield.

Chase-Dunn, Christopher, Thomas Reifer, Andrew Jorgenson, and Shoon Lio. 2005. "The Trajectory of the United States in the World-System: A Quantitative Reflection." Sociological Perspectives 48: 233-254.

Chomsky, Noam. 1998. Profit over People: Neoliberalism and Global Order. New York: Seven Stories Press.

--_----. 2001. 9/11. New York: Seven Stories Press.

Coker, Christopher, 2002. "Globalisation and Terrorism." Paper presented at a seminar on "The Prospects for the Canadian Summit," Nippon Press Center, Tokyo, Japan, June Io, 2002.

Cooper, H. H. A. 200I. "Terrorism: The Problem of Definition Revisited." American Behavioral Scientist 44:88I-893.

Correlates of War Project. 2005. "State System Membership List, v2004.I." Online: http://correlatesofwar.org.

Crenshaw, Martha. 198I. "The Causes of Terrorism." Comparative Politics I3: 379-399. --_-- I992. "Current Research on Terrorism: The Academic Perspective." Studies in Conflict and Terrorism I5: I-II.

Cronin, Audrey Kurth. 2002. "Behind the Curve: Globalization and International Terrorism." International Security 27: 30-58.

Denemark, Robert A. 2002. "Terrorism in the World System: Hypotheses for Core and Periphery." PP. 47-68 in Transnational Terrorism in the World System Perspective, edited by Ryszard Stemplowski. Warsaw: The Polish Institute of International Affairs.

Dollar, David, and Aart Kraay. 2002. "Spreading the Wealth." Foreign Affairs January/ February.

Eisenstein, Hester. 2002. "Globalization and the Events of September II." Socialism and Democracy I6: I3I-136. 
Enders, Walter, and Todd Sandler. 1999. "Transnational Terrorism in the Post-Cold War Era." International Studies Quarterly 43: 145-168. - 2002. "Patterns of Transnational Terrorism, 1970-1999: Alternative Time-Series Estimates." International Studies Quarterly 46: I45-166.

Featherstone, Mike. 1990. Global Culture, Nationalism and Modernity. London: Sage. Ferguson, Niall. 200I. "Clashing Civilizations or Mad Mullahs: The United States between Formal and Informal Empire." In The Age of Terror: America and the World After September 11, edited by Strobe Talbott and Nayan Chanda. New York: Basic Books.

Fox, Jonathan. 2002. "Religion and Terrorism in the World System." PP. 97-I20 in Transnational Terrorism in the World System Perspective, edited by Ryszard Stemplowski. Warsaw: The Polish Institute of International Affairs.

Friedland, Roger. 200I. "Religious Nationalism and the Problem of Collective Representation." Annual Review of Sociology 27: 125-I52.

Friedman, Thomas. 1999. The Lexus and the Olive Tree: Understanding Globalization. New York: Farrar, Straus \& Giroux.

Fukuyama, Francis. 1992. The End of History and the Last Man. New York: Free Press. Ganor, Boaz. 200I. "Terrorism: No Prohibition without Definition.” International Policy Institute for Counter-Terrorism. Online: http://www.ict.org.il/.

Ghosn, Faten, and Scott Bennett. 2003. Codebook for the Dyadic Militarized Interstate Incident Data, Version 3.o. Online: http://cow2.la.psu.edu.

Gibbs, Jack P. 1989. "Conceptualization of Terrorism." American Sociological Review 54: $329-340$.

Giddens, Anthony. 2002. Runaway World: How Globalization is Reshaping Our Lives. New York: Routledge.

Goodwin, Jeff. 2004. "A Theory of Categorical Terrorism." New York University, Unpublished Manuscript.

Gray, John. 2003. Al Qaeda and What it Means to Be Modern. London: Faber and Faber. Guillen, Mauro F. 200I. "Is Globalization Civilizing, Destructive or Feeble? A Critique of Five Key Debates in the Social Science Literature." Annual Review of Sociology 27:235-260.

Gurr, Ted Robert. 1970. Why Men Rebel. Princeton, NJ: Princeton University Press. Hardin, J., and J. Hilbe. 20oI. Generalized Linear Models and Extensions. College Station, TX: Stata Press.

Hannan, Michael T. 199I. "Theoretical and Methodological Issues in Analysis of Density-Dependent Legitimation in Organizational Evolution." Sociological Methodology. 2I: I-42.

Held, David. 1995. Democracy and Global Order. Cambridge, England: Polity Press.

Hess, Henner. 2003. "Like Zealots and Romans: Terrorism and Empire in the 2Ist Century." Crime, Law and Social Change 39: 339-357.

Hironaka, Ann. 2005. Neverending Wars: The International Community, Weak States, and the Perpetuation of Civil War. Cambridge, MA: Harvard University Press.

Hoffman, Bruce. 1992. "Current Research on Terrorism and Low-Intensity Conflict." Studies in Conflict and Terrorism I5(I): 25-38.
. I995. "'Holy Terror:' The Implications of Terrorism Motivated by a

Religious Imperative." Studies in Conflict and Terrorism I8: 27I-285.

1998. Inside Terrorism. London: Victor Gollancz.

- I999. "The Mind of the Terrorist: Perspectives from Social Psychology."

Psychiatric Annals 29: 337-340.

-- 2002. "Rethinking Terrorism and Counterterrorism since 9/II." Studies in

Conflict and Terrorism 25:303-316.

Huntington, Samuel P. 1997. The Clash of Civilizations and the Remaking of World

Order. New York: Simon \& Schuster.

Jenkins, Brian Michael. 200I. "Terrorism and Beyond: A 21st Century Perspective."

Studies in Conflict and Terrorism 24: 32I-327.

Joll, James. 1979. The Anarchists. London: Methuen.

Johnson, Chalmers. 2003. Blowback: The Costs and Consequences of American Empire. New York: Metropolitan Books.

Johnson, Larry C. 200I. "The Future of Terrorism." American Behavioral Scientist 44: $894-913$.

Joxe, Alain. 200I. The Empire of Disorder. New York: Semiotext(e).

Juergensmeyer, Mark. 2000. Terror in the Mind of God: The Global Rise of Religious

Violence. Berkeley, CA: University of California Press.

Kellner, Douglas. 2002. "Theorizing Globalization." Sociological Theory 20: 85-305.

Kentor, Jeffrey, and Terry Boswell. 2003. "Foreign Capital Dependence and

Development: A New Direction." American Sociological Review 68: 30I-3I3.

Kuran, Timur. 2002. "The Religious Undertow of Muslim Economic Grievances." pp. 67-74 in Understanding September 11: Perspectives from the Social Sciences, ed. Craig Calhoun, Paul Price, and Ashley Timmer. New York: New Press.

Laqueur, Walter. 1977. A History of Terrorism. New York: Little, Brown. 1987. The Age of Terrorism. London: Weidenfeld and Nicolson.

-. 1999. The New Terrorism: Fanaticism and the Arms of Mass Destruction.

New York: Oxford University Press.

Lechner, Frank J., and John Boli. 2005. World Culture: Origins and Consequences. New York: Blackwell.

Li, Quan, and Rafael Reuveny. 2003. "Economic Globalization and Democracy: An Empirical Analysis." British Journal of Political Science 33: 29-54.

Li, Quan, and Drew Schaub. 2004. "Economic Globalization and Transnational Terrorism: A Pooled Time-Series Analysis." Journal of Conflict Resolution 48: $230-258$.

Lizardo, Omar, and Albert J. Bergesen. 2003. “Types of Terrorism by World System Location." Humboldt Journal of Social Relations 27: 162-192.

Long, J. Scott. 1997. Regression Models for Categorical and Limited Dependent Variables. Thousand Oaks, CA: Sage Publications.

Lopez-Cordova, J. Ernesto, and Christopher Meissner. 2004. Globalization and Democracy, 1870-2000. Cambridge, MA: Cambridge University Press.

McAdam, Doug, Sidney Tarrow, and Charles Tilly. 200I. Dynamics of Contention. Cambridge, England: Cambridge University Press. 
McGrew, A. 1997. "Democracy Beyond Borders? Globalization and the Reconstruction of Democratic Theory And Practice." PP. 23I-266 in The Transformation of Democracy? Globalization and Territorial Democracy, edited by A. McGrew. Cambridge, England: Polity Press.

Meyer, John W., John Boli, George M. Thomas, and Francisco O. Ramirez. I997. "World Society and the Nation-State." American Journal of Sociology I03: I44-I8I.

Meyer, John W., and Ronald L. Jepperson. 2000. "The 'Actors' Of Modern Society: The Cultural Construction of Social Agency." Sociological Theory I8: I00-I20.

Midlarsky, M.I., M. Crenshaw, and F. Yoshida. I980. "Why Violence Spreads: The Contagion of International Terrorism." International Studies Quarterly 24: 262-298.

Munck, Ronaldo. 2002. "Globalization and Democracy: A New 'Great Transformation'?" Annals of the American Academy of Political and Social Science 58I: IO-2I.

Naim, Moises. 2003. "The Five Wars of Globalization." Foreign Policy $134 \div 28-38$.

Newey, W. K., and K. D. West. 1987. "A Simple, Positive Definite, Heteroskedasticity and Autocorrelation Consistent Covariance Matrix." Econometrica 55: 703-708.

Oliverio, Annamarie. 1998. The State Of Terror. Albany, NY: State University of New York Press.

Olzak, Susan. Forthcoming. The Global Dynamics of Race and Ethnic Mobilization. Stanford, CA: Stanford University Press.

Pasha, Mustapha Kamal. 2002. "Predatory Globalization and Democracy in the Islamic World." Annals of the American Academy of Political and Social Science 58I: $\mathrm{I} 2 \mathrm{I}-\mathrm{I} 32$.

Pluchinsky, Dennis. 1982. "Political Terrorism in Western Europe: Some Themes and Variations. PP. 40-78 in Terrorism in Europe, edited by Yonah Alexander and K. A. Myers. New York: St. Martins's Press.

-. 1987. "Middle Eastern Terrorist Activity in Western Europe in 1985: A Diagnosis and Prognosis." PP. I64-I78 in Contemporary Research on Terrorism, edited by Paul Wilkinson and A. M. Stewart. Aberdeen, Scotland: Aberdeen University Press.

Pollins, Brian M. 1996. "Global Political Order, Economic Change, and Armed Conflict: Coevolving Systems and the Use of Force." American Political Science Review 90: 103-II7.

Ranstorp, Magnus. I996. "Terrorism in the Name of Religion." Journal of International Affairs. 50: 4I-63.

Rapoport, David. 1988. "Messianic Sanctions for Terror." Comparative Politics 20: 195-213.

- I999. "Terrorism." In Encyclopedia of Violence, Peace and Conflict, edited by Lester R. Kurtz and Jennifer E. Turpin. London: Academic Press. -. 200I. "The Fourth Wave: September IIth in the History of Terrorism." Current History I00: 419-424.
Anti-U.S. Transnational Terrorism i97I-2000

Redlick, Amy Sands. 1979. "The Transnational Flow of Information as a Cause of Terrorism." PP. 73-96 in Terrorism: Theory and Practice, edited by Yonah Alexander, David Carlton, and Paul Wilkinson. Boulder, CO: Westview Press. Ritzer, George. 2003. "Rethinking Globalization: Glocalization/Grobalization and Something/Nothing" Sociological Theory 21: 193-209.

Ross, Jeffrey Ian. I993. "Structural Causes of Oppositional Political Terrorism: Towards a Causal Model." Journal of Peace Research 30: 317-329.

Ruby, Charles L. 2002. "The Definition of Terrorism." Analyses of Social Issues and Public Policy 2(2): 9-I4. http://www.asap-spssi.org/

Samiuddin, Abida. 1997. "Fundamentalism and the Rise of Terrorism in South Asia: Economic Political Factors." Philosophy and Social Action 23: 5-16.

Sandler Todd. 2003. "Collective Action and Transnational Terrorism." World Economy 26: $779-802$.

Sandler, Todd, and Walter Enders. 2004. "An Economic Perspective on Transnational Terrorism." European Journal of Political Economy 20: 30I-316.

Sandler, Todd, and Daniel Arce. 2003. "Terrorism and Game Theory." Simulation and Gaming 34: 319-337.

Sassen, Saskia. 1998. Globalization and Its Discontents. New York: New Press.

Schmid, Alex Peter, and A. J. Jongman. 1988. Political Terrorism. New York: Transaction Books.

Schwartzman, Kathleen C. 1998. "Globalization and Democracy." Annual Review of Sociology 24: I59-I8I.

Scholte, J. A. 2000. Globalization: A Critical Introduction. London: Macmillan.

Sobek, David, and Alex Braithwaite. 2005. "Victim of Success: American Dominance and Terrorism." Conflict Management and Peace Science 22: I35-I48.

Stern, Jessica. 1999. The Ultimate Terrorists. Cambridge, MA: Harvard University Press.

Stemplowski, Ryszard. 2002. Transnational Terrorism in the World System Perspective. Warsaw: The Polish Institute of International Affairs.

Strang, David, and John W. Meyer. I993. "Institutional Conditions for Diffusion." Theory and Society 22: 487-5II

Tarrow, Sidney. 2004. "Transnational Politics: Contention and Institutions in International Politics." Annual Review of Political Science 4: I-20.

Thomas, George M., and John W. Meyer. 1984. "The Expansion of the State." Annual Review of Sociology Io: 46I-482.

Thomas, George M., John W. Meyer, Francisco O. Ramirez, and John Boli. I987. Institutional Structure: Constituting State, Society and the Individual. Newbury Park, CA: Sage.

Tilly, Charles. 2004. "Trust and Rule." Theory and Society 33ः I-3I.

Virilio, Paul. 2004. "Delirious New York." PP. I9I-I96 in The Paul Virilio Reader, edited by Steve Readhead. New York: Columbia University Press.

Wade, Robert H. 2004. "Is Globalization Reducing Poverty and Inequality?" International Journal of Health Services 34: 38I-4I4. 
Weber, Max. 1946. From Max Weber: Essays in Sociology, edited by Hans Gerth and C.

Wright Mills. New York: Oxford University Press

Wilkinson, Paul. 1986. Terrorism and the Liberal State. London: Macmillan.

Willets, Peter. 1996. The Conscience of the World. Washington, DC: Brookings Institution.

Wolf, Martin. 2002. "Are Global Poverty and Inequality Getting Worse? Yes: Robert Wade, No: Martin Wolf." Prospect March: I6-2I. . 2004. Why Globalization Works. New Haven, CT: Yale University Press.

Zheng, B., and A. Agresti. 2000. "Summarizing the Predictive Power of a Generalized Linear Model." Statistics in Medicine I9: I77I-I78I.

Zizek, Slavoj. 200I. Welcome to the Desert of the Real. New York: Wooster Press. 